\title{
Length- weight relationship of twelve mesopelagic fishes from the western Tropical Atlantic
}

\author{
Nolé Eduardo Leandro 1, 2, ${ }^{*}$, Maia Mincarone Michael ${ }^{3}$, Lucena-Frédou Flavia ${ }^{1}$, \\ Rodrigues Martins Julia ${ }^{3}$, Vinícius Felix Afonso Gabriel ${ }^{3}$, Teixeira Villarins Barbara ${ }^{3}$, Frédou Thierry ${ }^{1}$, \\ Souza Lira Alex ${ }^{1}$, Bertrand Arnaud 1,2,4
}

1 Departamento de Pesca e Aquicultura, Universidade Federal Rural de Pernambuco, Recife, Brazil

2 Institut de Recherche pour le Développement (IRD), MARBEC (Université Montpellier, CNRS, Ifremer, IRD), Sète, France

${ }^{3}$ Instituto de Biodiversidade e Sustentabilidade, Universidade Federal do Rio de Janeiro, Macaé, Brazil

${ }^{4}$ Departamento de Oceanografia, Universidade Federal de Pernambuco, Recife, Brazil

* Corresponding author : Nolé Eduardo Leandro, email address : leandronole@hotmail.com

\begin{abstract}
:
Length-weight relationship parameters were calculated for twelve mesopelagic fish species from the western Tropical Atlantic: Diretmus argenteus, Melamphaes polylepis, Bolinichthys distofax, Diaphus lucidus, Diaphus splendidus, Electrona risso, Hygophum taaningi, Taaningichthys bathyphilus, Melanolagus bericoides, Winteria telescopa, Diplophos taenia, Astronesthes similus. Data was collected off northeastern Brazil from April 9th to May 6th, 2017. Hauls were conducted during day and night at 47 stations by using a micronekton trawl (body mesh: $40 \mathrm{~mm}$, cod-end mesh: $10 \mathrm{~mm}$ ) from 10 to $1,113 \mathrm{~m}$ depth. The material was fixed in a $4 \%$ formalin solution for 1 month and then preserved in a $70 \%$ alcohol solution for proximally 6 months before processing for length (nearest $0.1 \mathrm{~cm}$ of standard length) and weight (nearest $0.01 \mathrm{~g}$ of total weight). A new maximum standard length for Winteria telescopa is also provided.
\end{abstract}

Keywords : Brazil, deep-sea, lanternfish, oceanic islands, seamounts 


\section{INTRODUCTION}

Mesopelagic fishes (0-1,000 m depth) are major components of the oceans usually presenting global distribution, vertical migratory behavior, and a diverse array of morphological adaptations (Priede, 2017). These species are crucial for several ecosystem processes, such as carbon sequestration, nutrient regeneration, fisheries production, and waste absorption (Mengerink et al., 2014; Cavan et al., 2019; Eduardo et al., 2020). However, despite their importance, mesopelagic species remain mostly understudied and increasingly threatened by anthropogenic impacts (e.g. seabed mining, plastic pollution, ocean warming, and deoxygenation) (Steinberg et al., 2012; Mengerink et al., 2014; Levin \& Bris, 2015). Given the difficulty of sampling in the deep-sea, even basic biological knowledge is lacking for many species, hampering the sustainable management of mesopelagic species as well as the comprehension of their numerous functions in the ecosystem (e.g. transport of carbon between oceanic layers).

One of the key basic knowledge concerns the length-weight relationships (LWR), which is widely applied in the management of fish populations (Froese \& Binohlan, 2000; Froese, 2006; Froese et al., 2011). For example, LWR is an effective approach for assessing fish biomass based on the conveniently obtained length data (Froese, 2006). Additionally, this parameter may be used for ecological modeling, infer body condition indices, and estimating fish growth patterns as a part of stock assessment and conservation strategies (Froese, 2006; Eduardo et al., 2018). Nevertheless, available information on LWR of many mesopelagic species from the western Tropical Atlantic is still lacking (Catelani et al., 2017; Eduardo et al., 2018b, 2018c). In this study, we take advantage of a large-scale deep-sea expedition to provide new LWRs for twelve mesopelagic fish species. Data were acquired along the western Tropical Atlantic, a poorly studied area with a high biodiversity, where MPAs (Marine Protected Area) and EBSAs (Ecologically or Biologically Significant Marine Area) have been established (CBD, 2014; Eduardo et al., 2018a). Information provided herein aims to improve general knowledge and biological data on mesopelagic species.

\section{MATERIAL AND METHODS}

Samples were collected off northeast Brazil, including Rocas Atoll $\left(3^{\circ} 52^{\prime} \mathrm{S}, 33^{\circ} 49^{\prime} \mathrm{W}\right)$, Fernando de Noronha Archipelago $\left(3^{\circ} 50^{\prime} \mathrm{S}, 32^{\circ} 25^{\prime} \mathrm{W}\right)$ and adjacent seamounts. Data were collected during the ABRACOS 2 (Acoustics along the BRAzilian COaSt) expedition, carried out from April 9th to May 6th, 2017, onboard the French RV Antea (Bertrand, 2017). Sampling of mesopelagic fishes was conducted during day and night at 47 stations by using a micronekton 
trawl (body mesh: $40 \mathrm{~mm}$, cod-end mesh: $10 \mathrm{~mm}$ ) from 10 to $1,130 \mathrm{~m}$ depth. After capture, the material was fixed in a $4 \%$ formalin solution for one month and then preserved in a $70 \%$ alcohol solution for proximally six months before processing for length and weight. At the laboratory, specimens were identified, measured (nearest $0.1 \mathrm{~cm}$ of standard length, SL) and weighed (nearest $0.01 \mathrm{~g}$ of total weight, TW). Voucher specimens were deposited in the NPM - Fish Collection of the Instituto de Biodiversidade e Sustentabilidadae, Universidade Federal do Rio de Janeiro (UFRJ).

The LWR values were estimated using the equation: TW $=a \times \mathrm{SL}^{b}$, where TW is the total weight $(\mathrm{g})$; SL is the standard length $(\mathrm{cm}) ; a$ is the intercept of the regression curve (intercept of TW when SL is zero or initial growth coefficient) and $b$ is the regression slope (coefficient indicating isometric or allometric growth) (Froese, 2006; Froese et al., 2011). Prior to calculation of the LWR, outliers for each species were graphically identified using SL vs. TW plots (Froese \& Binohlan, 2000) and removed. The fit of the model to the data was measured by the coefficient of determination $r$-squared $\left(\mathrm{r}^{2}\right)$.

\section{RESULTS}

The study presents LWRs for twelve species, representing seven families and four orders (Table 1). Myctophidae is represented by six species, while the remaining families are represented by just one species. All regressions were highly significant $(p<0.01)$, with the coefficient of determination $\left(\mathrm{r}^{2}\right)$ ranging from 0.952 to 0.991 . The value of $b$ varied between 2.55 and 3.12, while the parameter $a$ ranged between 0.0038 and 0.0436. Summarized additional data including sample size (n), measurement range (SL and TW), regression parameters $a$ and $b$, and associated statistics are presented in Table 1 .

\section{DISCUSSION}

The present study provides the highest standard length values for Winteria telescopa and novel LWRs information for twelve species. All estimated values of the parameter $b$ fell within the expected range (2.5-3.5) predicted by Froese (2006). Thus, estimated values can be used within the referred length range. These equation parameters are the reflection of not only local environmental variations, but also intrinsic characteristics and adaptative processes of each species like ontogenetic reproductive and variations between sexes (Froese, 2006; Eduardo et al., 2018c). Since fixation in alcohol and formaldehyde can affect length and weight measurements through the shrinking and dehydration of specimens, LWRs presented here may be slightly different than those found for fresh specimens. For that reason, we thus recommend consider the parameters presented here as being tentative. Moreover, since shrinking in preservatives is time-dependent, we indicated the storage time before measurement. This is 
important as later studies, measuring freshly caught fish and preserving them for re-measurement after certain time intervals would offer an opportunity to provide a correction factor. Hence, data from previous studies who identified the time window under preservation can be re-calculated and incorporated in a time series analysis. We strongly recommend that all studies that need to preserve the samples before measurement register the time elapsed from preservation to measurement.

In conclusion, information provided here contributes to fill gaps in elementary biological knowledge and may, thus, give support to a sustainable management for the conservation of deep-sea species.

\section{ACKNOWLEDGMENTS}

We acknowledge the French oceanographic fleet for funding the at-sea survey ABRACOS 2 (http://dx.doi.org/10.17600/17004100) and the officers and crew of the RV Antea for their contribution to the success of the operations. The present study was also supported by the lab assistance of the BIOIMPACT (UFRPE) and LIZ (UFRJ) students. We thank the CNPq (Brazilian National Council for Scientific and Technological Development), which provided research grant to Flávia Lucena Frédou. The first author is supported by CAPES (88882.436215/2019-01) and FUNBIO/Humanize under the grant "Programa Bolsas Funbio Conservando o Futuro 2018 (011/2019)". This study is a contribution to the LMI TAPIOCA, program CAPES/COFECUB (88881.142689/2017-01), EU H2020 TRIATLAS project under Grant Agreement 817578. The NPM Fish Collection has been supported by the project MULTIPESCA (FUNBIO) under the grant 'Pesquisa Marinha e Pesqueira', contract 104/2016.

\section{CONFLICT OF INTEREST}

The authors declare no conflict of interest.

\section{DATA AVAILABILITY STATEMENT}

The data that support the findings of this study are available from the corresponding author upon request.

\section{REFERENCES}

Bertrand, A., 2017. ABRACOS 2 cruise, RV Antea. https://doi.org/10.17600/17004100. Accessed on: 2019-8-18.

Catelani, P. A., Bauer, A. B., \& Petry, A. C. (2017). Length-weight relationships of fishes from the estuary of the Macaé River, Southeastern Brazil. Journal of Applied Ichthyology, 
33(6), 1251-1253. https://doi.org/10.1111/jai.13443

Cavan, E. L., Laurenceau-Cornec, E. C., Bressac, M., \& Boyd, P. W. (2019). Exploring the ecology of the mesopelagic biological pump. Progress in Oceanography, 176, 102-125. https://doi.org/10.1016/j.pocean.2019.102125

CBD. (2014). Ecologically or Biologically Significant Marine Areas (EBSAs). Special places in the world's oceans. Wider Caribbean and western Mid-Atlantic (2nd ed.). Recife: Secretariat of the Convention on Biological Diversity.

Eduardo, L., Frédou, T., Lira, A. S., Ferreira, B. P., Bertrand, A., Ménard, F., \& Frédou, F. L. (2018a). Identifying key habitat and spatial patterns of fish biodiversity in the tropical Brazilian continental shelf. Continental Shelf Research, 166, 108-118. https://doi.org/10.1016/j.csr.2018.07.002

Eduardo, L. N., Frédou, T., Lira, A. S., Silva, L. V. S., Ferreira, B. P., Bertrand, A., ... LucenaFrédou, F. (2018b). Length-weight relationship of thirteen demersal fishes from the tropical Brazilian continental shelf. Journal of Applied Ichthyology, 35, 590-593. https://doi.org/10.1111/jai.13831

Eduardo, L. N., Mincarone, M. M., Villarins, B. T., Frédou, T., Lira, A. S., Bertrand, A., \& Lucena-Frédou, F. (2018c). Length-weight relationships of eleven mesopelagic fishes from oceanic islands of the Southwestern Tropical Atlantic. Journal of Applied Ichthyology, 35(2), 1-3. https://doi.org/10.1111/jai.13840

Eduardo, L. N., Bertrand, A., Mincarone, M. M.,, Santos, L., Frédou, T., Assunção, R. V., Silva, A., Ménard, F., Schwamborn, R., Le Loc'h, F., \& Lucena-Frédou, F. (2020). Hatchetfishes (Stomiiformes: Sternoptychidae) biodiversity, trophic ecology, vertical niche partitioning and functional roles in the western Tropical Atlantic. Progress in Oceanography, 186(June), 102389. https://doi.org/10.1016/j.pocean.2020.102389

Froese, R. (2006). Cube law, condition factor and weight-length relationships: history, metaanalysis and recommendations. Journal of Applied Ichthyology, 22(4), 241-253. https://doi.org/10.1111/j.1439-0426.2006.00805.x

Froese, R., \& Binohlan, C. (2000). Empirical relationships to estimate asymptotic length, length at first maturity and length at maximum yield per recruit in fishes, with a simple method to evaluate length frequency data. Journal of Fish Biology, 56(4), 758-773. https://doi.org/10.1006/jfbi.1999.1194

Froese, R., Tsikliras, A. C., \& Stergiou, K. I. (2011). Editorial note on weight-length relations 
of fishes. Acta Ichthyologica et Piscatoria, 41(4), 261-263.

https://doi.org/10.3750/AIP2011.41.4.01

Levin, L. A., \& Bris, N. L. (2015). The deep ocean under climate change. Science, 350(6262), 766-768. https://doi.org/10.1126/science.aad0126

Mengerink, K. J., Van Dover, C. L., Ardron, J., Baker, M., Escobar-Briones, E., Gjerde, K., ... Levin, L. A. (2014). A call for deep-ocean stewardship. Science, 344(6185), 696-698. https://doi.org/10.1126/science.1251458

Priede, I. G. (2017). Deep-sea fishes: Biology, diversity, ecology and fisheries. Cambridge: Cambridge University Press.

Steinberg, D. K., Martinson, D. G., \& Costa, D. P. (2012). Sustentabilty in deep water: the challenges of cimate change, human pressures, and biodiversity conservation. Oceanography, 25(3), 56-67. https://doi.org/10.5670/oceanog.2011.65 
Table 1. Descriptive statistics and parameters of LWRs for twelve mesopelagic fishes caught using a micronekton trawl (from 10 to $1,130 \mathrm{~m}$ depth) at the western Tropical Atlantic, from April 9th to May 6th, 2017. SL = Standard Length, TW = Total Weight, $\boldsymbol{a}=$ initial growth index, $\boldsymbol{b}=$ slope of the regression, and $\mathbf{r}^{2}=$ determination coefficient. *Estimative based on a limited size range and thus considered as tentative.

\begin{tabular}{|c|c|c|c|c|c|c|c|c|}
\hline \multirow{2}{*}{ Taxa } & \multirow{2}{*}{$n$} & \multicolumn{2}{|c|}{ SL (cm) } & \multicolumn{2}{|c|}{ TW (g) } & \multicolumn{2}{|c|}{ Regression parameters } & \multirow[t]{2}{*}{$\mathbf{r}^{2}$} \\
\hline & & Min & $\operatorname{Max}$ & Min & $\operatorname{Max}$ & $a(95 \% \mathrm{CI})$ & $b(95 \% \mathrm{CI})$ & \\
\hline \multicolumn{9}{|l|}{ Beryciformes } \\
\hline \multicolumn{9}{|l|}{ Diretmidae } \\
\hline Diretmus argenteus Johnson, 1864* & 116 & 1.4 & 7.5 & 0.1 & 17.9 & $0.0436(0.0370-0.0513)$ & $3.01(2.91-3.10)$ & 0.971 \\
\hline Melamphaidae & & & & & & & & \\
\hline Melamphaes polylepis Ebeling, 1962 & 37 & 3.6 & 6.9 & 0.8 & 6.4 & $0.0163(0.0103-0.0257)$ & $3.06(2.93-3.19)$ & 0.958 \\
\hline \multicolumn{9}{|l|}{ Myctophiformes } \\
\hline \multicolumn{9}{|l|}{ Myctophidae } \\
\hline Bolinichthys distofax Johnson, 1975 & 85 & 3.2 & 9.1 & 0.3 & 10.1 & $0.0126(0.0104-0.0153)$ & $3.03(2.92-3.14)$ & 0.974 \\
\hline Diaphus lucidus (Goode \& Bean, 1896) & 40 & 3.1 & 9.6 & 0.3 & 9.5 & $0.0161(0.0129-0.0200)$ & $2.82(2.71-2.93)$ & 0.986 \\
\hline Diaphus splendidus (Brauer, 1904) & 232 & 2.0 & 8.5 & 0.1 & 5.8 & $0.0079(0.0073-0.0083)$ & $3.10(3.06-3.14)$ & 0.991 \\
\hline Electrona risso $($ Сocco, 1829)* & 67 & 5.0 & 8.0 & 3.4 & 12.2 & $0.0365(0.0256-0.0519)$ & $2.78(2.60-2.97)$ & 0.952 \\
\hline Hygophum taaningi Becker, 1965 & 78 & 2.6 & 6.6 & 0.2 & 3.5 & $0.0180(0.0134-0.0242)$ & $2.86(2.68-3.05)$ & 0.957 \\
\hline Taaningichthys bathyphilus (Tåning, 1928) & 10 & 5.4 & 7.1 & 1 & 2.4 & $0.0113(0.0059-0.0214)$ & $2.73(2.52-2.92)$ & 0.976 \\
\hline \multicolumn{9}{|l|}{ Argentiniformes } \\
\hline \multicolumn{9}{|l|}{ Bathylagidae } \\
\hline Melanolagus bericoides (Borodin, 1929)* & 9 & 12.8 & 16.7 & 12 & 26 & $0.0038(0.0012-0.0063)$ & $3.12(2.77-3.47)$ & 0.963 \\
\hline \multicolumn{9}{|l|}{ Opisthoproctidae } \\
\hline Winteria telescopa Brauer, 1901* & 26 & 5.1 & 11.8 & 1 & 10.4 & $0.0081(0.0036-0.0178)$ & $2.92(2.58-3.28)$ & 0.964 \\
\hline \multicolumn{9}{|l|}{ Stomiiformes } \\
\hline \multicolumn{9}{|l|}{ Gonostomatidae } \\
\hline Diplophos taenia Günther, 1873* & 23 & 4.2 & 12.9 & 0.8 & 14.9 & $0.0161(0.0090-0.0287)$ & $2.80(2.69-2.91)$ & 0.952 \\
\hline Stomiidae & & & & & & & & \\
\hline Astronesthes similus Parr, 1927* & 9 & 3.6 & 7.5 & 0.2 & 1.7 & $0.0107(0.0058-0.0119)$ & $2.55(2.43-2.67)$ & 0.976 \\
\hline
\end{tabular}

